\title{
U.S. Geological Survey Programs in Oklahoma
}

\section{U.S. Department of the Interior - U.S. Geological Survey}

The mission of the U. S. Geological Survey (USGS) is to provide the information needed to understand, manage, and use the Nation's natural resources. Geologic, hydrologic and biologic data collected by the USGS are used by other Federal, state, tribal, and local agencies and individuals for a variety of purposes. USGS methods, techniques, computer programs, and data are used widely.

\section{Flooding}

Major floods in Oklahoma have affected many people and have caused economic damage and loss of life. Although floods cannot be prevented, information furnished by the USGS is critical to the operation of flood-warning systems and alerts. Information on the amount of water in reservoirs, river stages, and the arrival of floodwaters helps people prepare for flooding, thus lessening the destructive effects of floods.

Information furnished by the USGS to the National Weather Service Tulsa River Forecast Center is used to predict maxi- mum river heights and the probable extent of flooding. Reservoir managers use the information, as well as predictive models and past experience, to regulate incoming floodwaters. Civil defense agencies use this information to warn people in the pathway of the flood so they can avoid the worst of the flood or protect their property against floodwaters.

Record floods occurred on June 3, 1995, on the Elm Fork of the North Fork Red River in southwestern Oklahoma (fig. 1). The USGS measured 60,000 cubic feet per second (cfs) of flow at the streamflow gaging station on the State Highway 30 bridge. The 100-year flood for the Elm Fork at this site, which is based on 20 years of record, is 29,800 cfs. The "100-year flood" is a flood that has a chance of 1 in 100 of occurring in any year. The mean annual discharge for the Elm Fork is $42 \mathrm{cfs}$. The previous record flood was 22,100 cfs on May 17, 1977.

The Red River near Gainesville, Texas, was at flood stage at 7:30 a.m. on June 9, 1995. The USGS measured $155,800 \mathrm{cfs}$ of flow at the streamflow gaging station on

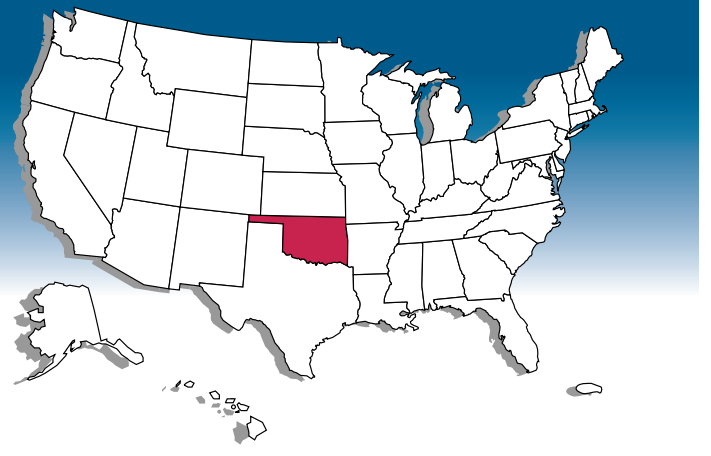

Index of Subjects

Flooding

Surface- and Ground-Water Information

Geologic Mapping

Topographic Mapping

Cooperative Programs

Sharing Spatial Data

Earth Science Information

Wildlife and Aquatic Resources in Oklahoma

Water Contamination

National Oil and Gas Assessment

the Interstate Highway 35 bridge, which is 31 miles south of Ardmore, Oklahoma. The 100-year flood for the Red River at this site, which is based on 46 years of record, is $189,000 \mathrm{cfs}$. The mean annual discharge for the Red River at Gainesville is 3,227 cfs. The record flood is 256,000 cfs on May 31, 1987.

After flooding has passed, the USGS, in cooperation with Federal, State, tribal, and local agencies, studies the extent of the flooding and the weather patterns and rainfall intensity that led to the flooding. As an important part of its fact-finding efforts, the USGS evaluates and maps the
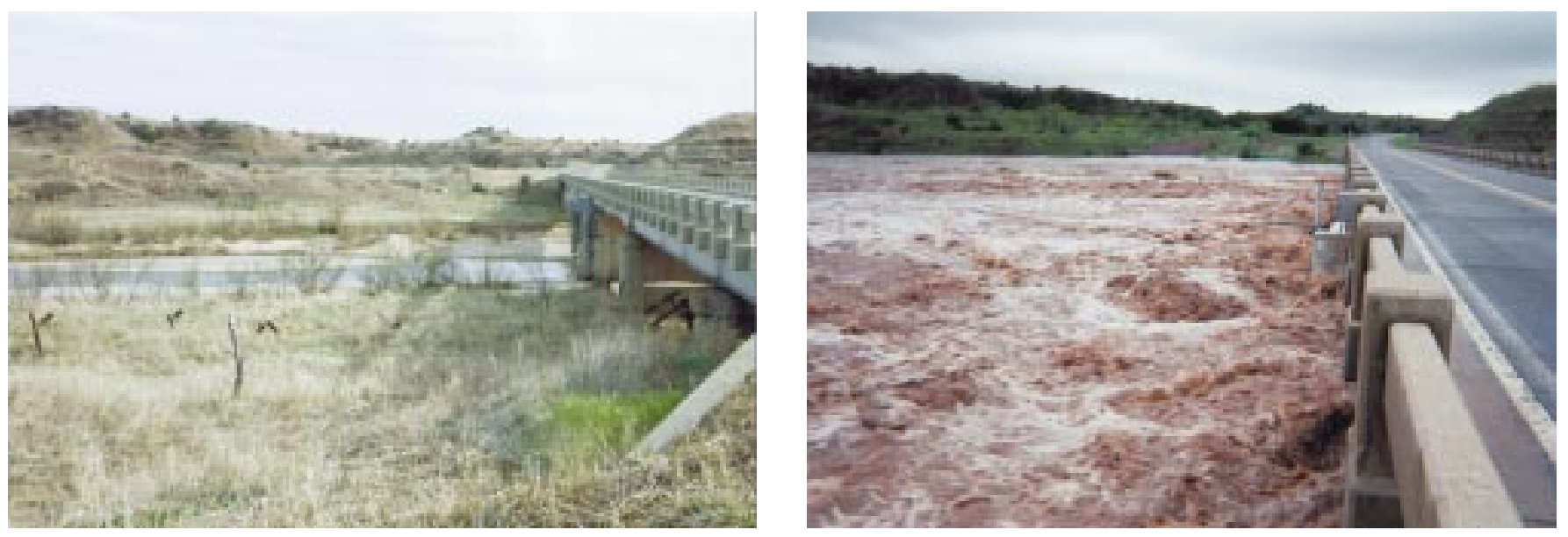

Figure 1. Left, August 24, 1994, during base-flow conditions at the Elm Fork of the North Fork Red River near Carl, Oklahoma. Right, June 3, 1995, near the peak of record flow of 62,300 cubic feet per second. 
extent of flooding and attempts to determine how often floods of that magnitude may be expected to recur. The USGS also maps the movement of streambanks caused by powerful floodwaters. Bridges may be washed out or their piers undermined by swiftly flowing water. By using computer models, a prediction can be made of conditions that might weaken or threaten a structure so that preventive steps can be taken by the appropriate agency to lessen the hazard.

In addition to studying the effects of flooding, the USGS has prepared maps that show the probable extent of flooding for many urban areas throughout Oklahoma. Maps of these flood-prone areas, which show the approximate boundaries of the 100-year floods, are used extensively to plan locations of homes, offices, and industries. Studies of specific communities or localities for use in planning and community development are made by the USGS in cooperation with the Federal Emergency Management Agency.

The USGS also provides information on how often a flood that inundates a specific area may be expected to happen again in any year. This information is useful in designing flood-control structures, such as dams, retarding structures, holding ponds, and spillways. Although flooding may be expected for specific areas, information on the frequency of flooding can aid community planners in flood-plain development. Long-term monitoring of streamflow and flood flows provide the data needed for statistical analyses of floods and the prediction of future flooding.

\section{Surface- and Ground-Water Information}

Accurate knowledge of the quantity and quality of surface- and ground-water resources is vital to the citizens of Oklahoma. The state depends on information gathered by the USGS and the Oklahoma Water Resources Board and on interpretations of these data to determine water rights.

Continuous measurements of flow are needed by those who manage surface-water supplies. The determination of the amount of surface-water flow in
Oklahoma is of great importance to the irrigators of the State, particularly in western Oklahoma. In central and eastern Oklahoma, surface water is used by many communities as the primary source of public water supply (fig. 2).

One of the principal continuing duties of the USGS throughout the United States is the measurement of flow in the Nation's rivers and streams. In Oklahoma, the USGS maintains an extensive network of about 150 streamflow monitoring stations. Many of these stations transmit data by satellite; these data are valuable in flood monitoring and prediction. Daily flow values from all Oklahoma stations are published yearly.

The USGS, in cooperation with the Oklahoma Water Resources Board, monitors water levels in key wells throughout the State. Water levels in other wells are measured in conjunction with specific projects and many additional wells are measured annually by the Oklahoma Water Resources Board.

The USGS, in cooperation with State and local agencies, has completed appraisals of ground-water availability and quality in many areas of Oklahoma. Many of the aquifers in the state have been studied by using a USGS-developed ground-water flow model. For instance, the model predicted water-level changes in the Antlers aquifer in southeastern Oklahoma in response to various hypothetical pumping rates at 10 -year increments for several decades into the next century.

A ground-water flow model also was developed to study the alluvial and terrace deposits associated with the Cimarron

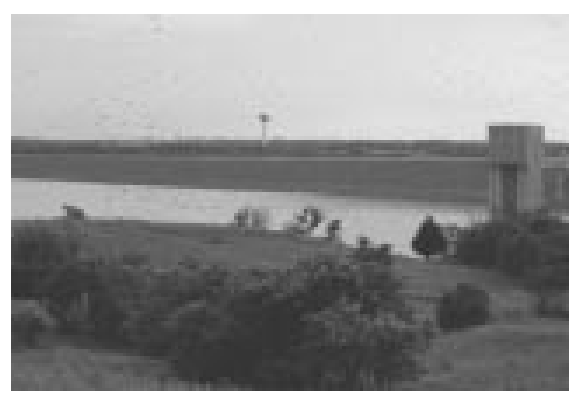

Figure 2. Lake Arcadia Reservoir supplies drinking water and recreation for the Oklahoma City metropolitan area.
River in northwestern Oklahoma. The aquifer is well connected to the Cimarron River, and has an average saturated thickness of 28 feet with an estimated 4.47 million acre-feet of water in storage. The model will be useful to the Oklahoma Water Resources Board in managing the ground-water resources of the area. A similar model recently was developed for the Blaine aquifer in southwestern Oklahoma and northwestern Texas.

The Arbuckle-Simpson aquifer, in south-central Oklahoma, has been the focus of several recent studies conducted by the USGS in cooperation with Federal and state agencies and the city of Ada. A multiday aquifer stress test evaluated the effects of municipal ground-water withdrawals on the hydrologic system. Simultaneous pumping of two municipal wells for 241 hours at a combined average rate of 3,900 gallons per minute resulted in a maximum observed drawdown of 1.3 feet, recorded at an average distance of 1.1 miles from the pumped wells. Geophysical and geochemical data have been collected in an effort to understand groundwater flow in this aquifer.

\section{Geologic Mapping}

The National Cooperative Geologic Mapping Act became law in 1992. The Act was the result of a collaborative effort by the USGS and the Association of American State Geologists to develop STATEMAP, a program to accelerate the detailed geologic mapping in areas of critical need in the United States. Through the state mapping component of the Act, matching Federal funds are made available to states to develop geologic-map coverage of priority areas.

This program, and its predecessor effort, COGEOMAP, have produced detailed geologic mapping of 24 quadrangles in the Ouachita Mountains of southeastern Oklahoma. These quadrangle maps are available from the Oklahoma Geological Survey. With the printing of the Savanna and the McAlester geologic quadrangle maps, a six-map block in the McAlester area will be completed. In addition, the 1996-97 program initiated the development of digital geologic maps at a scale of 1:100,000. 


\section{Topographic Mapping}

Among the most popular and versatile products of the USGS are its 1:24,000scale topographic maps (1 inch on the map represents 2,000 feet on the ground). About 1,240 maps cover Oklahoma.

These maps have long been favorites with the general public for outdoor uses, including hiking, camping, exploring, and back-country fishing expeditions.

\section{Cooperative Programs}

The USGS, in cooperation with the Oklahoma Department of Transportation (OkDOT), is producing updated digital line graphs (DLG's) to be used for development, planning, and management decisions relevant to the transportation network in Oklahoma. The USGS and the OkDOT also are cooperatively funding statewide coverage of digital raster graphics products in Oklahoma. The USGS, in cooperation with Oklahoma State University's Department of Agronomy, is jointly producing digital elevation models (DEM's) that can be used with hydrologic data for modeling water flow, inundation studies, and hydrologic planning and management decisions.

The USGS and the Oklahoma Water Resources Board jointly produced 1:24,000-scale hydrography Digital Line Graphs (DLG's). These DLG's can be used with DEM data for watershed delineation and hydrologic planning and management decisions by Federal, State, Tribal and local agencies.

\section{Sharing Spatial Data}

The cooperative production and sharing of geospatial data provides cost savings for cooperating agencies at every level of government, increases the amount of data available, and reduces duplication of data production efforts.

The USGS, in cooperation with the Oklahoma Sate University Environmental Institute, the Oklahoma GIS Council, and the Oklahoma State Geographer, is developing an interactive geographic information system for the State. The objective is to provide a centralized source for searching, evaluating, and accessing geospatial data sets. The two principal efforts are to create an inventory and to record and catalog metadata in accordance with the Content Standards for Digital Geospatial Metadata and to establish and maintain a node on the National Geospatial Data Clearinghouse.

\section{Earth Science Information}

The Earth Science Information Centers (ESIC's) provide information about USGS programs, products, and technological developments to the public. The ESIC in Norman was established under a cooperative agreement between the USGS and the Geology Library at the University of Oklahoma. As part of the national ESIC network, this office provides information on such earth-science topics as cartography, geography, digital data, remote sensing, geology, geophysics, geochemistry, hydrology, geohydrology, aerial photography and land use. It is supported by the USGS with reference materials, technical assistance, training and outreach activities, and access to USGS data bases.

\section{Wildlife and Aquatic Resources in Oklahoma}

The USGS Biological Resources Division (formerly the National Biological Service) conducts research and provides the scientific data needed for sustained economic benefits from, and conservation of, the grassland ecosystems of the Great Plains. USGS research activities include studying the biology, status, and habitat requirements of endangered fish, such as the leopard darter, the Arkansas darter, and the speckled chub; documenting the wildlife values of the Conservation Reserve Program, which removed about 36 million acres of marginal farmland from agricultural production nationwide and enhanced its value for wildlife; and collecting biological information in the Ozark Plateau as part of the National Water-Quality Assessment Program.

The Oklahoma Cooperative Fish and Wildlife Research Unit, located at Oklahoma State University, conducts research on smallmouth and striped bass in the eastern part of the state, where they are an important recreational resource, and is participating in the Gap Analysis Program to improve access to the state's biological resources.

\section{Water Contamination}

Contamination of our surface-water and ground-water resources is one of the most pressing issues in the management of the Nation's natural resources. The USGS has sampled the rivers, wells, and springs at about 25,000 sites in Oklahoma. These samples have been analyzed for a broad range of inorganic and organic substances, which includes pesticides and herbicides, that might affect the suitability of the water for human consumption or nonconsumptive use. Results of chemical analyses of ground-water samples generally are published at the end of a project; results of surface-water analyses are published annually.

The USGS is investigating possible ground- and surface-water contamination at many sites. At Altus Air Force Base in southwestern Oklahoma, the USGS is studying possible ground-water contamination that results from past use of solvents and cleaning solutions for aircraft maintenance and repair activities at the air base. Information on the presence and concentration of contaminants on Federal lands, such as Altus Air Force Base, is useful to determine the necessity for remediation of the contamination. The USGS has just completed a study of water quality and water movement within the aquifer underlying central Oklahoma. Determination of natural movement and chemical change within the aquifer was a primary objective of the project. The study indicated that most of the aquifer is uncontaminated and that further development of the aquifer for drinking water is possible. The USGS, in cooperation with the city of Norman, is studying the processes that control movement of possible contaminants within and from an old landfill near Norman.

Rural residents in western Oklahoma use ground water primarily for household use. The USGS recently compiled data for nitrogen and phosphorus concentrations in water from these aquifers. The results can be used to set priorities for groundwater protection. 
Alteration of land use in Hackberry Flat (fig. 3), a wetlands restoration project in southwestern Oklahoma, operated by the Oklahoma Department of Wildlife Conservation (ODWC), could mobilize natural elements and manmade organic compounds that are in the soils. The USGS, in cooperation with the ODWC, is establishing base-line environmental conditions at Hackberry Flat on the basis of analysis of 182 soil samples. The results of this study will help the ODWC evaluate environmental factors that affect migrating waterfowl at the wetlands restoration site.

The State of Oklahoma regulates the discharge of pollutants to streams so that streams do not exceed a permissible limit for pollutants. To set a limit on the effluent discharge concentration, the chemical content and flow of the effluent-receiving streams must be known. Data collected, analyzed, recorded, and distributed by the USGS help state agencies determine the values used in issuing discharge permits.

Data collected by the USGS can help regulatory agencies maintain and improve the chemical quality of water in aquifers and streams within Oklahoma by providing base-line data against which changes may be compared and evaluated. Agencies rely on data furnished by the USGS to design protection strategies for water use. Evaluation of water-quality information will help water users realize the full potential of the use of water-how, for what, and in what quantities it might be used and the possible effects of using the water.

Determination of water quality in Oklahoma's lakes, streams, and aquifers has become increasingly important with population growth and need for usable water. The USGS has collected extensive data on water quality within Oklahoma for use by cooperators.

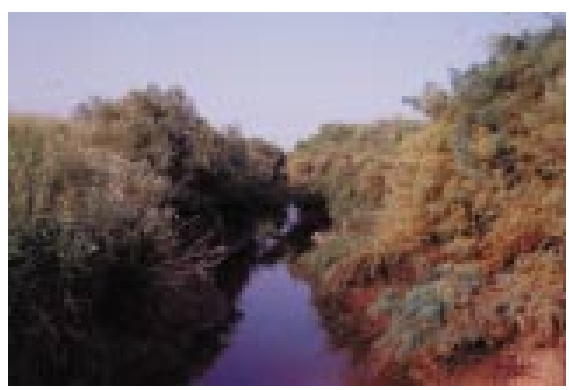

Figure 3. Hackberry Flat is the site of a wetlands restoration project.

\section{National Oil and Gas Assessment}

The USGS, as part of the ongoing National Oil and Gas Assessment Project, completed and released the 1995 National Assessment of United States Oil and Gas Resources in early 1995 . The assessment was released on CD-ROM as U.S. Geological Survey Digital Data Series DDS30. This CD-ROM, which can be viewed on many types of personal computers, contains maps and text for the U.S. provinces and plays included in the assessment, a discussion of the methods used, and the results. The maps show drilling intensity and locations and types of petroleum production for individual plays. Oklahoma holds a significant position in U.S. petroleum production because a large part has come from the Anadarko Basin Province, most of which lies in Oklahoma. Production from the Province was assigned to 25 individual plays. Deeper, less well explored parts of the province may contain significant quantities of undiscovered natural gas.

A series of map sheets show drilling intensity, petroleum producing wells locations of major fields used in the assessment, drilling depths to the top of major producing units, and tabular data for the major fields for the Anadarko Basin Province. The first three sheets of this series - covering the Arbuckle, Simpson, and the Viola Groups - have been completed.
USGS state representative 202 NW 66 Street,

Building 7

Oklahoma City, OK 73116

Telephone: (405) 843-7570

Fax: (405) 843-7712

Email: info_ok@usgs.gov

Additional earth science information can be found by accessing the USGS Home Page

on the World Wide Web at http://www.usgs.gov/

For more information on all USGS reports and products (including maps, images, and computerized data), call 1-800-USA-MAPS

The USGS provides maps, reports, and information to help others meet their needs to manage, develop, and protect America's water, energy, mineral, biological, and land resources. We help find the natural resources needed to build tomorrow, and supply the scientific understanding needed to help minimize or mitigate the effects of natural hazards and environmental damage caused by natural and human activities. The results of our efforts touch the daily life of almost every American. 
FrameMaker has detected one or more Postscript errors in this document. (Genevieve Comfort)

Please check your output. 